\title{
Sensitization of breast cancer cells to taxol by inhibition of taxol resistance gene 1
}

\author{
ZHIGANG BAI, ZHONGTAO ZHANG, XIANG QU, WEI HAN and XUEMEI MA \\ Department of General Surgery, Beijing Friendship Hospital, Capital Medical University, Beijing 100050, P.R. China
}

Received May 6, 2011; Accepted August 26, 2011

DOI: $10.3892 / \mathrm{ol} .2011 .416$

\begin{abstract}
The purpose of this study was to determine the role of taxol resistance gene 1 (TXR1) in a taxol-resistant breast cancer cell line. Expression levels of TXR1 and thrombospondin-1 (TSP1) were detected by RT-PCR and Western blot analysis. In MCF-7 cells transfected with TXR1 plasmids, the expression of a number of drug resistance genes was monitored, as well as cell proliferation. MCF-7 cells were also transiently transfected with a chemically synthesized small interfering RNA (siRNA) targeting TXR1. Taxol concentrations varying from 0.6 to $6 \mu \mathrm{g} / \mathrm{ml}$ were shown to inhibit the proliferation of MCF-7 cells in a time- and dose-dependent manner by arresting cells in the $\mathrm{G} 2 / \mathrm{M}$ phase. Additionally, $0.06 \mu \mathrm{g} / \mathrm{ml}$ taxol was used to establish a taxol-resistant MCF-7 cell line, MCF-7/T. When TXR1 was exogenously expressed, a taxol-resistant phenotype was further induced and the expression levels of BCRP, GSTP1 and MVP increased. Transient transfection of TXR1-targeting siRNAs was shown to restore the chemosensitivity of MCF-7 cells. These results suggest that an increased expression of TXR1 is a novel mechanism for reversing the taxol resistance of breast cancer cells.
\end{abstract}

\section{Introduction}

Breast cancer is a significant threat to women's health, and with increasing rates of incidence, it is currently one of the most common malignancies in women. However, as diagnostic tools and treatment methods continue to improve, a decrease in the mortality rate for breast cancer patients has been observed (1). Currently, the clinical treatment for breast cancer includes surgery, chemotherapy, radiotherapy and endocrine therapy to provide a comprehensive treatment regimen. The therapeutic effect of this combination of treatments has also become more effective with the introduction of new therapeutic drugs (2). In

Correspondence to: Professor Zhongtao Zhang, Department of General Surgery, Beijing Friendship Hospital, Capital Medical University, 95 Yongan Road, Xuanwu, Beijing 100050, P.R. China E-mail: zhangzht@yahoo.com.cn

Key words: taxol resistance, breast cancer, multidrug resistance, taxol resistance gene 1, thrombospondin-1 particular, the availability of taxane drugs has improved the effectiveness of chemotherapy treatments for breast cancer.

Taxol (paclitaxel) was identified as a drug that is capable of inhibiting microtubule depolymerization, and as such, may prevent spindle formation, cause cell cycle arrest in the $\mathrm{G} 2 / \mathrm{M}$ phase and terminate mitosis (3). In the clinic, application of taxol was shown to have a significant therapeutic effect on ovarian, breast, non-small cell lung and head and neck cancer (4). However, not all cell types were sensitive to the effects of taxol. Multidrug resistance (MDR) is currently a leading cause of insensitivity to chemotherapy, and taxol resistance was observed shortly after its application $(5,6)$. Additional studies indicated that molecules which interfered with the binding of taxol to microtubules (7) or the increased expression of the drug transporter protein, P-glycoprotein (8), may result in taxol resistance (9). More recently, a series of apoptosis-related genes, including bcl-2, p53 and erbB2, and related enzymes such as PKC and telomerase, have been found to play key roles in taxol resistance (10). Despite these valuable insights, the study of taxol and other anti-cancer drug resistance mechanisms are being investigated to identify specific mechanisms for taxol resistance (11).

Cohen et al (12) identified the taxol resistance gene 1 (TXR1) and showed that it reduced the secretion of the apoptosis-inducing protein, thrombospondin-1 (TSP1). TSP1 has been shown to induce apoptosis and inhibit angiogenesis (13), roles that are consistent with a taxol-resistant phenotype. Furthermore, Papadaki et al detected the transcription of TXR1 and TSP1 in fresh tumor tissues obtained from 96 patients with non-small cell lung cancer that had not received pre-operative chemotherapy. For this cohort, a high expression of TSP1 and a low expression of TXR1 were associated with an improved prognosis (14). In the present study, expression of TXR1 and TSP1 were monitored in the taxol-resistant breast cancer cell line, MCF-7, to determine the role of TXR1 in taxol resistance.

\section{Materials and methods}

Reagents and cell lines. Taxo1 (Concord Pharmaceutical, China), TRIzol, Lipofectamine ${ }^{\mathrm{TM}} 2000$ (Invitrogen, Carlsbad, CA, USA), MMLV reverse transcriptase (Promega, Madison, WI, USA) and BCA protein assay kits (Pierce, Rockford, IL, USA) were purchased as listed. Methyl thiazolyl tetrazolium (MTT), dimethyl sulfoxide (DMSO) and propidium iodide (PI) were purchased from Sigma (St. Louis, MO, USA). 
Antibodies used included TXR1 rabbit anti-human polyclonal antibody (a gift from Professor S. Cohen, Stanford University, USA) (12), TSP1 rabbit anti-human polyclonal antibody (BA2130, Wuhan Boster) and mouse anti-human $\beta$-actin monoclonal antibody (Sigma). The human breast cancer cell lines, MCF-7 and MCF-7/ADR, were purchased from American Type Culture Collection (ATCC) and were cultured in complete Dulbecco's modified Eagle's medium (DMEM) (Hyclone) containing 10\% fetal bovine serum (FBS) (Gibco, Carlsbad, CA, USA) at $37^{\circ} \mathrm{C}$ in a humidified atmosphere containing $5 \% \mathrm{CO}_{2}$.

Constructed plasmids. For TXR1-GFP, the human TXR1 (NM_018457.2) cDNA clone (OriGene clone SC113472) was subcloned by PCR into pEGFP-C3 (Clontech) using the primers (5'-XhoI and 3'-BamHI sites are underlined): 5'-CCG CTC GAG ATG TGG AAT CCC AAT GCC-3' (forward) and 5'-CGC GGA TCC TCA GTC AGA ATC ACT GCT GGA-3' (reverse). Sequencing confirmed the clones were generated.

Transfection. Cells were plated and grown to 70-90\% confluence without antibiotics. Transfections were then performed using Lipofectamine ${ }^{\mathrm{TM}} 2000$ (Invitrogen) according to the manufacturer's instructions. To obtain stable cell lines, cells were transiently transfected with TXR1-expressing vectors and selected with $400 \mu \mathrm{g} / \mathrm{ml} \mathrm{G} 418$ for 28 days. Experiments using transiently transfected cells were performed $48 \mathrm{~h}$ following transfection.

Small interfering RNA (siRNA)-mediated downregulation of gene expression. Two sets of siRNA duplexes specific for TXR1 were chemically synthesized (Invitrogen): siRNA duplex 1, (sense) 5'-CAG UGA UAG UAG ACA AGA ATT-3, (anti-sense) 5'-UUCUUGUCUACU AUCACU GTT-3; siRNA duplex 2, (sense) 5'-GGU UAG AUC AUA UAG CUA ATT-3', (anti-sense) 5'-UUA GCU AUA UGA UCU AAC CTT-3'. These duplexes were designed based on sequences at nucleotide (nt) 469 and nt 813 of the TXR1 mRNA sequence, NM_018457, respectively. A chemically synthesized mock siRNA (fluorescein-labeled, non-silencing) was also purchased from Invitrogen. Transfection of these oligos (50 nM) was performed using Lipofectamine ${ }^{\mathrm{TM}} 2000$ (Invitrogen). For RNA extraction, cells were harvested $48 \mathrm{~h}$ following transfection. To measure drug cytotoxicity, cells were grown in 6-well plates and sub-cultured into 96-well plates $24 \mathrm{~h}$ following transfection.

Selection of a taxol-resistant cell line. The human breast cancer cell line, MCF-7, was maintained in RPMI-1640 containing $1 \%$ penicillin-streptomycin (Gibco) and 10\% FBS. $\mathrm{MCF}-7$ cells were selected for resistance to taxol in a stepwise manner as previously described (15). Briefly, MCF-7 cells were exposed to $0.001 \mu \mathrm{g} / \mathrm{ml}$ taxol. Once normal growth was achieved, the cells were maintained at this concentration for 21 days prior to the drug dose being increased. MCF-7/T cells were maintained at a final concentration of $0.06 \mu \mathrm{g} / \mathrm{ml}$ taxol.

Growth inhibition assays. Growth rates of cells in culture were determined using MTT assays. Briefly, MCF-7 cells were plated (2x10 $/ 200 \mu \mathrm{l}$ medium) in 96-well plates and grown under normal conditions for $24 \mathrm{~h}$. Various concentrations of taxol $(0.006,0.06,0.6,6$ and $60 \mu \mathrm{g} / \mathrm{ml})$ were then added, and 24, 48, 72 and $96 \mathrm{~h}$ following the addition of taxol, $20 \mu \mathrm{l} \mathrm{MTT}(5 \mathrm{mg} /$ $\mathrm{ml}$ ) was added. Four hours later, $100 \mu \mathrm{l}$ DMSO was added to each well and absorbance values were determined using a microplate reader (Bio-Rad, Hercules, CA, USA) at $570 \mathrm{~nm}$. The IC50 value was estimated using the SPSS software.

Flow cytometry. Cells $\left(5 \times 10^{5}\right)$ were harvested and washed with phosphate-buffered saline (PBS), then fixed in cold $75 \%$ ethanol overnight at $4^{\circ} \mathrm{C}$. Following staining with PI solution for $30 \mathrm{~min}$, cells were detected on a FACScan flow cytometer and analyzed using CellQuest software (BectonDickinson, San Jose, CA, USA).

Reverse transcription PCR. Total RNA from cells was extracted using TRIzol reagent (Invitrogen), and cDNA libraries were generated using reverse transcription reactions containing M-MLV reverse transcriptase and oligo dT primers. The primers used for gene amplification are listed in Table I. PCR assays included a $5 \mathrm{~min}$ incubation at $94^{\circ} \mathrm{C}$, $30-32$ cycles of $94^{\circ} \mathrm{C}$ for $30 \mathrm{sec}, 60^{\circ} \mathrm{C}$ for $30 \mathrm{sec}$, and $72^{\circ} \mathrm{C}$ for $30 \mathrm{sec}$, followed by $5 \mathrm{~min}$ at $72^{\circ} \mathrm{C}$. The $\beta$-actin gene was used as an internal control.

Quantitative real-time PCR. Quantitative PCR was performed using the Applied Biosystems Sequence Detection System 7900 (Applied Biosystems Company, CA, USA). A $10 \mu 1$ mixture containing Power SYBR-Green PCR MasterMix (Applied Biosystems Company), $500 \mathrm{nmol}$ for each primer and $300 \mathrm{ng}$ cDNA templates were incubated at $95^{\circ} \mathrm{C}$ for $5 \mathrm{~min}$, followed by 50 cycles of $94^{\circ} \mathrm{C}$ for $20 \mathrm{sec}, 60^{\circ} \mathrm{C}$ for $20 \mathrm{sec}$, and $72^{\circ} \mathrm{C}$ for $40 \mathrm{sec}$, with a final extension at $72^{\circ} \mathrm{C}$ for $5 \mathrm{~min}$. A temperature ramp was then performed from 72 to $95^{\circ} \mathrm{C}$ at a rate of $0.1^{\circ} \mathrm{C} / \mathrm{sec}$ with continuous fluorescent acquisition. Copy numbers of the mRNAs detected were then quantified by calculating the $\mathrm{CT}$ values from the melt curves generated.

Western blot analysis. Total protein was extracted from cells in the logarithmic phase of growth and quantified using the BCA method. Equal amounts of protein were electrophoresed on 12-15\% SDS-PAGE and electro-transferred to PVDF membranes using Mini-PROTEAN 3 systems (Bio-Rad). PVDF membranes were blocked with PBS containing $5 \%$ fat-free milk powder for $2 \mathrm{~h}$, and then incubated with primary antibodies overnight at $4{ }^{\circ} \mathrm{C}$. Anti-mouse or antirabbit $\operatorname{IgG}$ secondary antibodies conjugated to horseradish peroxidase (HRP) were incubated with the membranes, and peroxidase activity was visualized using enhanced chemiluminescence (GE Healthcare, UK).

Statistical analysis. Data were analyzed by a paired-sample t-test or an independent sample t-test, using SPSS 11.0 software. $\mathrm{P}<0.05$ was considered to be statistically significant.

\section{Results}

Taxol affects TXR1 response in MCF7 breast cancer cells. Various concentrations of taxol $(60,6,0.6,0.06$ and 
Table I. Primer sequences for real-time PCR.

\begin{tabular}{|c|c|c|c|}
\hline Gene target & Primer & Sequence $\left(5^{\prime} \rightarrow 3^{\prime}\right)$ & Product size (bp) \\
\hline TXR1 & $\begin{array}{l}\text { Foward } \\
\text { Reverse }\end{array}$ & $\begin{array}{l}\text { GGACCСТTCССТCAAGTCTC } \\
\text { CTCTTCССАTTTCСССТАGC }\end{array}$ & 157 \\
\hline TSP1 & $\begin{array}{l}\text { Foward } \\
\text { Reverse }\end{array}$ & $\begin{array}{l}\text { GCTGGTGGTAGACTAGGGTTGTTT } \\
\text { CCAGAAGGTGCAATACCAGCAT }\end{array}$ & 143 \\
\hline BCRP & $\begin{array}{l}\text { Foward } \\
\text { Reverse }\end{array}$ & $\begin{array}{l}\text { TGAGCCTTTGGTTAAGACCG } \\
\text { TGGTGTTTCCTTGTGACACTG }\end{array}$ & 107 \\
\hline GSTP1 & $\begin{array}{l}\text { Foward } \\
\text { Reverse }\end{array}$ & $\begin{array}{l}\text { ACCTCCGCTGCAAATACATC } \\
\text { CTCAAAAGGCTTCAGTTGCC }\end{array}$ & 98 \\
\hline MDR1 & $\begin{array}{l}\text { Foward } \\
\text { Reverse }\end{array}$ & $\begin{array}{l}\text { GGCTCCGATACATGGTTTTCC } \\
\text { CCAGTGGTGTTTTTAGGGTCATC }\end{array}$ & 76 \\
\hline MRP1 & $\begin{array}{l}\text { Foward } \\
\text { Reverse }\end{array}$ & $\begin{array}{l}\text { GTTTCTCAGATCGCTCACCC } \\
\text { TCCACCAGAAGGTGATCCTC }\end{array}$ & 102 \\
\hline MRP2 & $\begin{array}{l}\text { Foward } \\
\text { Reverse }\end{array}$ & $\begin{array}{l}\text { CCAGCTCTATGGCTGCTAGAA } \\
\text { CCACTTTGTTTTGAGCAAACTGT }\end{array}$ & 181 \\
\hline MVP & $\begin{array}{l}\text { Foward } \\
\text { Reverse }\end{array}$ & $\begin{array}{l}\text { CTGGGAGTTGGTGGTGATCT } \\
\text { CAACTGGCACTTTGAGGTGA }\end{array}$ & 379 \\
\hline TOP2A & $\begin{array}{l}\text { Foward } \\
\text { Reverse }\end{array}$ & $\begin{array}{l}\text { TTTGACCACGCGGAGAAG } \\
\text { GAGTCCATCAGATTTGTGGAA }\end{array}$ & 170 \\
\hline$\beta$-actin & $\begin{array}{l}\text { Foward } \\
\text { Reverse }\end{array}$ & $\begin{array}{l}\text { TCCCTGGAGAAGAGCTACGA } \\
\text { AAAGCCATGCCAATCTCATC }\end{array}$ & 509 \\
\hline GAPDH & $\begin{array}{l}\text { Foward } \\
\text { Reverse }\end{array}$ & $\begin{array}{l}\text { CCTGCCAAGTATGATGACATCAAGA } \\
\text { GTAGCCCAGGATGCCCTTTAGT }\end{array}$ & 66 \\
\hline
\end{tabular}

$0.006 \mu \mathrm{g} / \mathrm{ml}$ ) were assayed for their ability to affect the growth of MCF-7 cells in MTT assays. Cell viability was observed to decrease with higher concentrations of taxol and longer incubation periods $(\mathrm{P}<0.01$, Fig. 1A). Based on these experiments, taxol concentrations of 6 and $0.6 \mu \mathrm{g} / \mathrm{ml}$ were selected for further study. Under these conditions FACS analysis revealed the induction of G2/M arrest (Fig. 1B). Of note, taxol treatment $(0.6 \mu \mathrm{g} / \mathrm{ml}$ for 24 and $48 \mathrm{~h})$ resulted in an induction of the TXR1 gene and a downregulation of its downstream target TSP1, as shown by real-time PCR (Fig. 1C), RT-PCR (Fig. 1D) and Western blot analysis (Fig. 1E). These data suggest that TXR1 is a taxol-inducible gene in MCF7 cells.

Taxol resistance in MCF7 correlates with upregulation of TXR1. To confirm the role of TXR1 in taxol sensitivity of MCF7 cells, we established a taxol-resistant MCF-7 cell line, MCF-7/T, by exposing MCF-7 cells to stepwise increases in taxol concentrations ( 0.01 to $0.2 \mu \mathrm{g} / \mathrm{ml}$ for 5 months). No difference in the proliferation rate was observed for MCF-7/T vs. the parental cell line under standard culture conditions (data not shown). By contrast, under taxol challenge $(0.06 \mu \mathrm{g} /$ $\mathrm{ml}$ for $0-96 \mathrm{~h}$ or $0-60 \mu \mathrm{g} / \mathrm{ml}$ for $48 \mathrm{~h}$ ), MCF-7/T cells were significantly more resistant to taxol-induced toxicity compared to the parental cell line as assessed by MTT assay (Figs. 2A and B). This resistant phenotype was associated with a constitutive overexpression of TXR1 and MDR1 genes, and downregulation of TSP1 (Fig. 2C), supporting the hypothesis that, besides MDR1, TXR1 may play a significant role in taxol resistance in breast cancer cells.

Downregulation of TXR1 reverses the taxol-resistant phenotype in MCF 7 cells. To confirm this conclusion, two different siRNAs (siRNA1, siRNA2; $25 \mathrm{nM}$ ) directed against TXR1 were singularly transfected into $\mathrm{MCF}-7 / \mathrm{T}$ cells. An irrelevant siRNA sequence was used as a control. A 60-80\% decrease in TXR1 expression and an increase in TSP1 (200-250\%) expression were detected in siRNA1- and siRNA2-transfected cells, compared to siRNA control-transfected cells, as assessed by real-time PCR $48 \mathrm{~h}$ post-transfection. A downregulation of MDR1 was also observed (Fig. 2C). Accordingly, a significant enhancement in chemosensitivity (taxol, $0.06 \mu \mathrm{g} / \mathrm{ml}$ for $0-96 \mathrm{~h}$ or $0-60 \mu \mathrm{g} / \mathrm{ml}$ taxol for $48 \mathrm{~h}$ ), and therefore a rescue of the resistant phenotype was observed in MCF-7/T cells following TXR1 silencing, as assessed by the MTT assay (Figs. 2A and B, $\mathrm{P}<0.01$ for the two siRNAs). Thus, TXR1 expression plays a significant role in the taxol resistance of MCF7 cells.

Ectopic TXR1 expression induces taxol resistance in MCF7 cells. To confirm the role of TXR1 in modulating the response to taxol in breast cancer cells, TXR1 (pEGFP-TXR1) was ectopically expressed by stable transfection in MCF7 cells (MCF-7-TXR1). As a control, cells were transfected with the corresponding empty vector (pEGFP) (MCF-7-EGFP). While MCF-7-TXR1 and MCF-7-EGFP cells exhibited no difference 
A

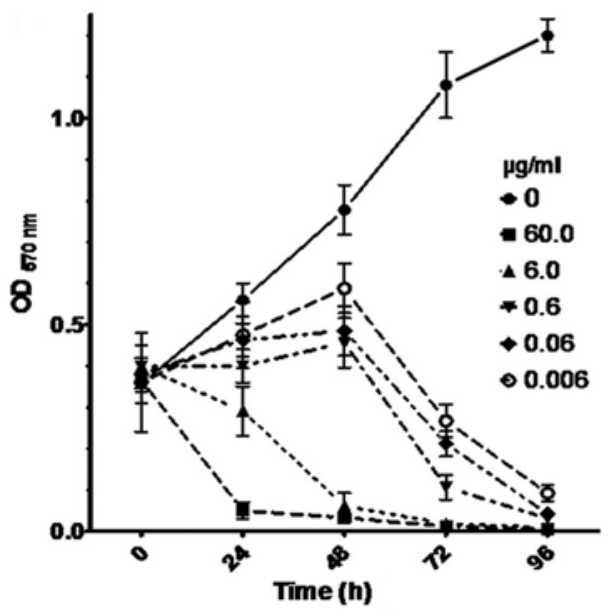

C

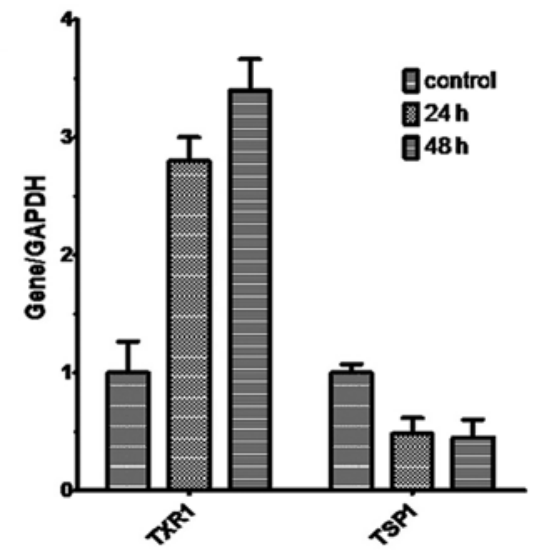

B
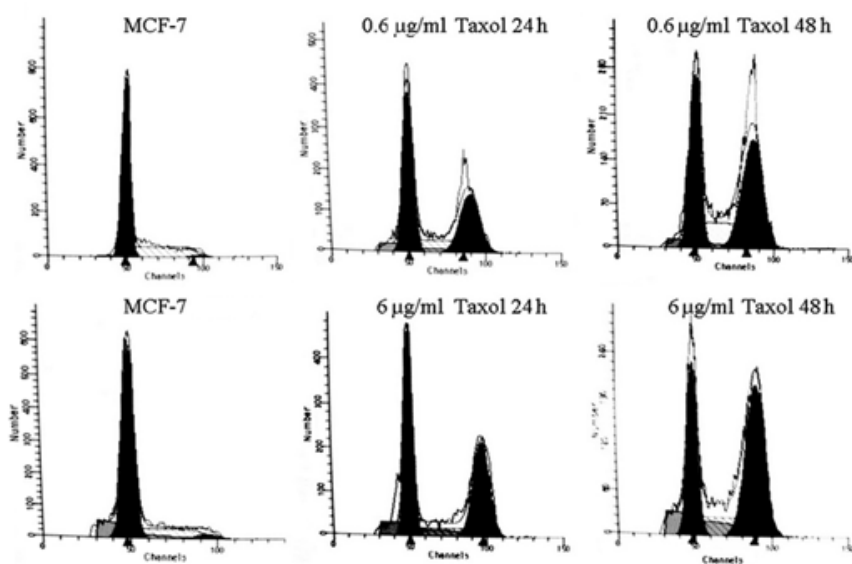

$6 \mu \mathrm{g} / \mathrm{ml} \mathrm{Taxol} 48 \mathrm{~h}$

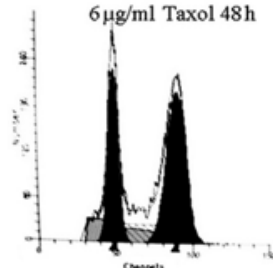

D

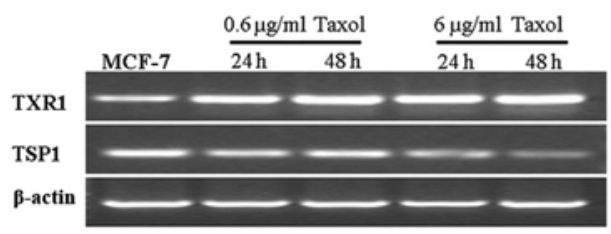

E

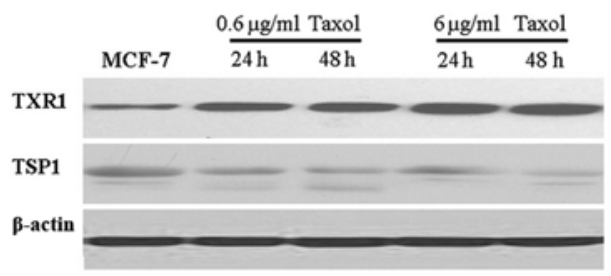

Figure 1. Effects of taxol on the proliferation and cell cycle progression of MCF-7 cells. (A) Cell proliferation of MCF-7 cells incubated with various concentrations of taxol $(60,6,0.6,0.06$ and $0.006 \mu \mathrm{g} / \mathrm{ml})$ were monitored using MTT assays. Each data point is the mean of three independent experiments \pm SD (B) Flow cytometry analysis 24 and $48 \mathrm{~h}$ after MCF-7 cells were treated with 0.6 or $6 \mu \mathrm{g} / \mathrm{ml}$ taxol. The percentage of cells in the G2/M-phase vs. control cells was significantly higher $(\mathrm{P}<0.01)$, while the percentage of cells in the G0/G1 and S phases decreased. (C) Real-time PCR analysis of TXR1 and TSP1 mRNA levels normalized to levels of GAPDH in control cells vs. MCF-7 cells treated with $0.6 \mu \mathrm{g} / \mathrm{ml}$ taxol. Assays were performed at 24 and $48 \mathrm{~h}$ time points. (D and E) RT-PCR analysis and Western blot analysis, respectively, of TXR1 and TSP1 levels in MCF-7 cells treated with 0.6 and $6 \mu \mathrm{g} / \mathrm{ml}$ taxol for 24 and $48 \mathrm{~h}$.

A

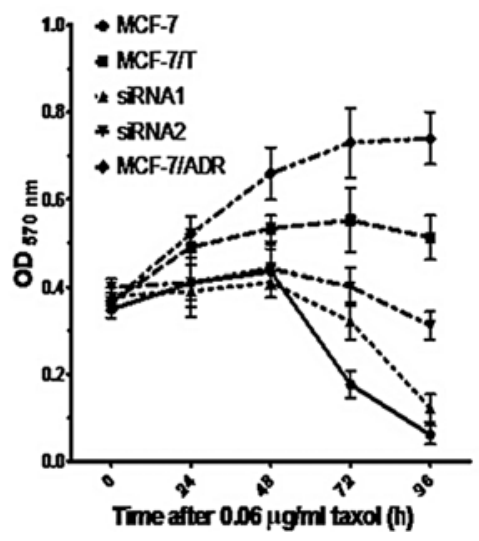

B

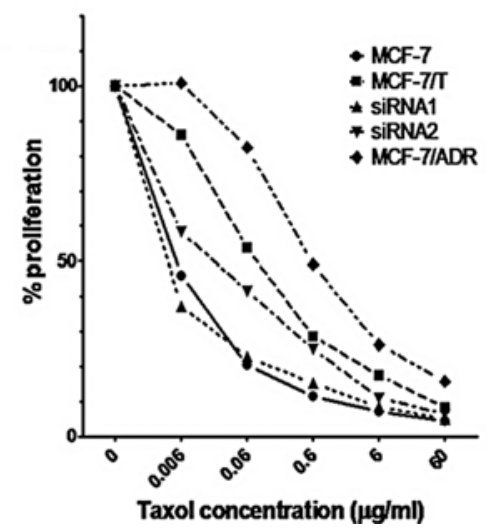

C

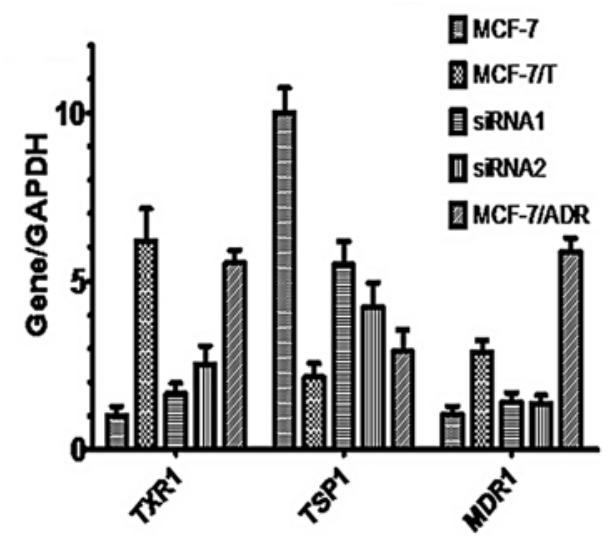

Figure 2. Gene expression following transfection of TXR1-targeted siRNA. (A) MTT assays were used to evaluate the effect of taxol on the proliferation of MCF-7, MCF-7/T and MCF-7/T-siRNA cell lines. A significant enhancement in the chemosensitivity of MCF-7/T cells transfected with siRNA was observed $(\mathrm{P}<0.01)$, with siRNA1 associated with a slightly greater effect than siRNA2 $(\mathrm{P}<0.05)$. (B) MTT assays were used to monitor the effect of taxol on MCF-7, MCF-7/T and MCF-7/T-siRNA cell lines. MCF-7/T cells were 20 -fold more resistant to taxol compared to MCF-7 cells, and MCF-7/T-siRNA cells were 10-fold more sensitive to taxol than MCF-7/T cells. (C) Levels of TXR1, TSP1 and MDR1 were monitored by real-time PCR and normalized to GAPDH in MCF-7 and MCF-7/T cells vs. MCF-7/T cells transfected with TXR1-targeted siRNA. 
A

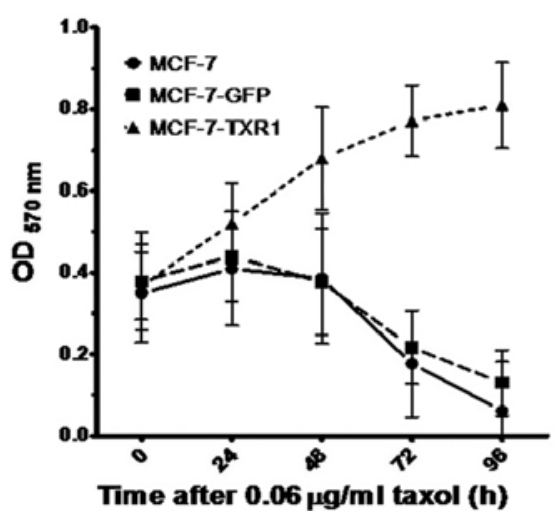

B

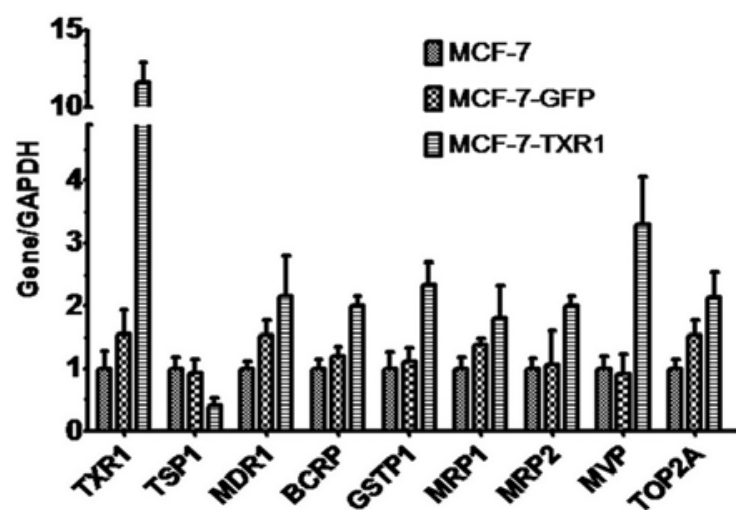

Figure 3. Transcription of drug resistance genes with TXR1 overexpression and treatment with taxol. (A) MTT assays of MCF-7, MCF-7-EGFP, and MCF-7TXR1 cell lines treated with $0.06 \mu \mathrm{g} / \mathrm{ml}$ taxol. Taxol did not inhibit the growth of MCF-7-TXR1 cells and overexpression of TXR1 enhanced the taxol resistance of MCF-7 cells. (B) mRNA levels of TXR1, TSP1, BCRP, GSTP1, MDR1, MRP1, MRP2, MVP and TOP2A were detected using real-time PCR and normalized to GAPDH for MCF-7, MCF-7-EGFP and MCF-7-TXR1 cell lines. Overexpression of TXR1 was associated with a relative increase in TXR1 mRNA, a decrease in TSP1 mRNA and an increase in the drug resistance genes BCRP, GSTP1 and MVP.

in terms of morphology or the cell proliferation rate under standard culture conditions (data not shown), enforced TXR1 expression correlated with an increased drug resistance under taxol challenge $(0.06 \mu \mathrm{g} / \mathrm{ml}$ for $0-96 \mathrm{~h})$ (Fig. 3A, $\mathrm{P}<0.01)$. Moreover, TXR1-expressing cells exhibited downregulation of TSP1, but also increased levels of other drug resistance genes including BCRP, GSTP1 and MVP, as determined by real-time PCR (Fig. 3B).

\section{Discussion}

In this study, MCF-7 cells that were resistant to low doses of taxol had higher levels of TXR1, and MCF-7 cells with an exogenous expression of TXR1 exhibited an increase in taxol resistance. By contrast, when TXR 1 expression was reduced by the transient transfection of TXR1-targeted siRNAs, the chemosensitivity of the transfected cells increased significantly, leading to the hypothesis that TXR1 has a significant role in mediating taxol resistance and complements mechanisms of MDR.

Paclitaxel affects tubulin polymerization to promote the stability of microtubules (16), resulting in the accumulation of intracellular microtubules and the breakdown of mitotic spindles to arrest cell cycle progression in the G2/M phase, or cause apoptosis (17). Similar to other anti-cancer drugs, tumor cells have also been found to become taxane-resistant (18). In these cells, an increased capacity to break down drugs, as well as an increase in expression of the MDR protein, P-glycoprotein (P-gp), is most frequently observed (19). Other characteristics of multi-drug resistant cells include activation of drug efflux pumps, increased drug transport, metabolic changes and increased DNA repair due to drug damage (20,21). A variety of specific molecules have been identified that promote drug resistance in breast cancer cells, including MDR1, MRP, GSTP1 and Topo II (22). However, the expression levels of a number of these molecules are not high, suggesting that there are multiple pathways that have a role in mediating drug resistance.

Cohen et al first characterized the txrl gene as encoding an $18 \mathrm{kDa}$ proline and serine-rich protein with nuclear expression and a role in taxol resistance. These authors also demonstrated that TXR1 is capable of inhibiting TSP1 expression at the transcriptional level, thereby preventing taxol-induced apoptosis in human tumor cells. Inactivations of TXR1 by CD47, or activation of TSP1, were also shown to enhance taxolinduced cytotoxicity in tumor cells. In combination, results by these authors suggested that TXR1, as a thrombin-mediated regulator, was a potential therapeutic target (12). However, the correlation between TXR1 and drug resistance in breast cancer remained to be investigated. Results of this study have shown TXR1 to be highly expressed in the taxol-resistant breast cancer cell line MCF-7/T. Additionally, results of the MTT assay show that these high expression levels decreased the sensitivity of the breast cancer cells to taxol. Furthermore, when TXR1-targeted siRNAs were transiently expressed, the taxol sensitivity of the MCF-7/T cells was reversed, thereby supporting a role for TXR1 in the taxol-resistant phenotype of breast cancer cells. Based on these results, we hypothesize that TXR1-targeted siRNAs are also capable of increasing the chemosensitivity of other types of breast cancer cells.

While transcription and translation of TXR1 were found to increase with exposure of MCF-7 cells to taxol, mRNA and protein levels of TSP1 have been found to decrease. Accordingly, when TXR1 was overexpressed, the taxol resistance of MCF-7 cells increased, and expression of TSP1 significantly decreased. Further experiments to modulate TXR1 expression using siRNA demonstrated have shown that MCF-7/T cells are capable of having their sensitivity to taxol restored, suggesting that the increase in taxol resistance mediated by TXR1 is due to the inhibition of TSP1 expression. However, despite this valuable insight into a possible mechanism for taxol-induced drug resistance in breast cancer cells, the interactions between TSP1 and TXR1 remain unclear. On the other hand, the ectopic expression of TXR1 is associated with the upregulation of a number of genes associated with drug resistance (BCRP, GSTP1 and MVP), which reflects the complexity of the TXR1 resistance mechanism, and not only with apoptosis. Further elucidation of the interactions between these molecules and their regulation would not only contribute to our understanding of taxol resistance 
but also identify novel therapeutic targets that may restore the therapeutic effect of taxol and improve the prognosis of patients with breast cancer.

\section{References}

1. Marsh S and McLeod HL: Pharmacogenetics and oncology treatment for breast cancer. Expert Opin Pharmacother 8: $119-127,2007$.

2. Moore A: Breast-cancer therapy-looking back to the future. N Engl J Med 357: 1547-1549, 2007.

3. Horwitz SB: Mechanism of action of taxol. Trends Pharmacol Sci 13: 134-136, 1992.

4. Sparano JA, Wang M, Martino S, Jones V, Perez EA, Saphner T, Wolff AC, Sledge GW Jr, Wood WC and Davidson NE: Weekly paclitaxel in the adjuvant treatment of breast cancer. New Engl J Med 358: 1663-1671, 2008.

5. Broxterman HJ, Gotink KJ and Verheul HM: Understanding the causes of multidrug resistance in cancer: a comparison of doxorubicin and sunitinib. Drug Resist Updat 12: 114-126, 2009.

6. Sangrajrang $\mathrm{S}$ and Fellous A: Taxol resistance. Chemotherapy 46: 327-334, 2000

7. Martello LA, Verdier-Pinard P, Shen HJ, He L, Torres K, Orr GA and Horwitz SB: Elevated levels of microtubule destabilizing factors in a taxol-resistant/dependent A549 cell line with an alpha-tubulin mutation. Cancer Res 63: 1207-1213, 2003.

8. Gottesman MM, Fojo T and Bates SE: Multidrug resistance in cancer: role of ATP-dependent transporters. Nat Rev Cancer 2: 48-58, 2002.

9. Ferguson T, Wilcken N, Vagg R, Ghersi D and Nowak AK: Taxanes for adjuvant treatment of early breast cancer. Cochrane Database Syst Rev 17: CD004421, 2007.

10. Kutuk $\mathrm{O}$ and Letai A: Alteration of the mitochondrial apoptotic pathway is key to acquired paclitaxel resistance and can be reversed by ABT-737. Cancer Res 68: 7985-7994, 2008.

11. Hudis $C$ and Dang C: The taxane limbo: how low can we go? J Natl Cancer Inst 100: 761-763, 2008.
12. Lih CJ, Wei W and Cohen SN: Txr1: a transcriptional regulator of thrombospondin-1 that modulates cellular sensitivity to taxanes. Genes Dev 20: 2082-2095, 2006.

13. Nor JE, Mitra RS, Sutorik MM, Mooney DJ, Castle VP and Polverini PJ: Thrombospondin-1 induces endothelial cell apoptosis and inhibits angiogenesis by activating the caspase death pathway. J Vasc Res 37: 209-218, 2000.

14. Papadaki C, Mavroudis D, Trypaki M, Koutsopoulos A Stathopoulos E, Hatzidaki D, Tsakalaki E, Georgoulias V and Souglakos J: Tumoral Expression of TXR1 and TSP1 predicts overall survival of patients with lung adenocarcinoma treated with first-line docetaxel-gemcitabine regimen. Clin Cancer Res 15: 3827-3833, 2009.

15. Greenberger LM, Lothstein L, Williams SS and Horwitz SB: Distinct P-glycoprotein precursors are overproduced in independently isolated drug-resistant cell lines. Proc Natl Acad Sci USA 85: 3762-3766, 1988.

16. Jordan MA and Wilson L: Microtubules as a target for anticancer drugs. Nat Rev Cancer 4: 253-265, 2004.

17. Van Amerongen R and Berns A: TXR1-mediated thrombospondin repression: a novel mechanism of resistance to taxanes? Genes Dev 20: 1975-1981, 2006.

18. Orr GA, Verdier-Pinard P, McDaid H and Horwitz SB: Mechanisms of taxol resistance related to microtubules. Oncogene 22: 7280-7295, 2003.

19. Ark-Otte J, Samelis G, Rubio G, Lopez Saez JB, Pinedo HM and Giaccone G: Effects of tubulin-inhibiting agents in human lung and breast cancer cell lines with different multidrug resistance phenotypes. Oncol Rep 5: 249-255, 1998.

20. McGrogan BT, Gilmartin B, Carney DN and McCann A: Taxanes, microtubules and chemoresistant breast cancer. Biochim Biophys Acta 1785: 96-132, 2008.

21. Lavie Y, Cao H, Volner A, Lucci A, Han TY, Geffen V, Giuliano AE and Cabot MC: Agents that reverse multidrug resistance, tamoxifen, verapamil, and cyclosporin A, block glycosphingolipid metabolism by inhibiting ceramide glycosylation in human cancer cells. J Biol Chem 272: 1682-1687, 1997.

22. Longley D and Johnston P: Molecular mechanisms of drug resistance. J Pathol 205: 275-292, 2005. 